\title{
Hubungan Persepsi Siswa Dalam Metode Mengajar Guru Terhadap Hasil Belajar Siswa Teknik Kendaraarn Ringan di SMK N 8 Padang
}

\author{
Ilma Putra ${ }^{1 *}$, Remon Lapisa ${ }^{1}$, Martias $^{1}$ \\ ${ }^{1}$ Jurusan Teknik Otomotif, Fakultas Teknik, Universitas Negeri Padang \\ Jln. Prof. Dr. Hamka Air Tawar Padang 25131 INDONESIA \\ *e-mail: ilma.falcao09@gmail.com
}

(Diajukan: 10 September 2020, direvisi: 1 Oktober 2020, disetujui: 31 Oktober 2020)

\begin{abstract}
Abstrak
Penelitian ini membahas tentang hubungan persepsi siswa dalam metode mengajar guru terhadap hasil belajar siswa yang di latar belakangi pada masalah masih kurangnya perhataian, tanggapan dan respon siswa terhadap materi yang disampaikan oleh guru dalam proses pembelajaran di kelas. Jenis penelitian ini adalah penelitian kuantitatif bersifat korelasional. Populasi dalam penelitian ini yaitu siswa kelas XI Program Keahlian Teknik Kendaraan Ringan SMK 8 Padang yang berjumlah 45 siswa. Jenis analisis data yang digunakan teknik adalah teknik analisis korelasi Product Moment. Hasil dari analisis di peroleh (1) koefisien korelasi $r$ hitung $(0,957)>r$ tabel $(0,355)$ serta $t$ hitung $(17,769)>t$ tabel $(1,699)$ pada taraf signifikansi 5\%, (2) koefisien korelasi $r$ hitung $(0,964)>\mathrm{r}$ tabel $(0,355)$ serta $t$ hitung $(19,522)>\mathrm{t}$ tabel $(1,699)$ pada taraf signifikansi 5\%. Berdasarkan hasil penelitian, disimpulkan bahwa persepsi siswa dalam metode mengajar guru memiliki hubungan positif dan signifikan terhadap hasil belajar.
\end{abstract}

Kata Kunci: Persepsi Siswa, Metode Mengajar Guru, Hasil Belajar Siswa.

\begin{abstract}
This study discusses the relationship between student perceptions in the teaching method of teachers to student learning outcomes in the background of the lack of attention, student responses and responses to the material presented by the teacher in the learning process in the classroom. This type of research is correlational quantitative research. The population in this study were 45 students of class XI at SMK 8 Padang. The type of data analysis technique used is the Product Moment correlation analysis technique. The results of the analysis are (1) the correlation coefficient $r$ count (0.957)> $r$ table (0.355) and $t$ count (17.769)> t table (1.699) at the 5\% significance level, (2) the correlation coefficient $r$ count (0.964)> $r$ table (0.355) and t count (19.522)> t table (1.699) at the 5\% significance level. Based on the results of the study, it was concluded that students' perceptions of teacher teaching methods had a positive and significant relationship to learning outcomes.
\end{abstract}

Keywords: students perception, teacher teaching method, students achievement. 


\section{PENDAHULUAN}

Guru dalam kegiatan pembelajaran akan selalu diamati, diperhatikan, didengar, ditiru dan bahkan dinilai oleh siswanya mengenai penampilan di kelas, kepribadiannya, cara guru berkomunikasi dengan siswa, perhatian terhadap siswa, hubungan antara siswa dengan guru, sikap dan tingkah lakunya, kemampuan guru dalam menguasai materi pelajaran, kompetensi yang dimiliki oleh seorang guru serta metode mengajar yang diterapkan oleh guru selama kegiatan pembelajaran berlangsung. Berdasarkan pada hal tersebut, pada diri siswa akan terbentuk suatu persepsi terhadap guru yang mengajar tersebut.

Kompetensi diartikan sebagai pengetahuan, keterampilan, dan kemampuan yang dikuasai oleh seseorang yang telah menjadi bagian dari dirinya, sehingga dapat melakukan perilaku- perilaku kognitif, afektif, dan psikomotor dengan sebaik-baiknya. Indikator tercapainya kompetensi, yang secara keseluruhan dapat diaplikasikan dalam kegiatan pembelajaran dengan fleksibel dan adaptable sesuai kondisi serta kebutuhan setempat, baik kebutuhan siswa maupun kebutuhan masyarakat, sehingga memberikan ruang bagi guru untuk melakukan manuver dan inovasi guna mencapai pembelajaran yang efektif, efisien, dan relevan. Penjelasan kompetensi ini terdapat dalam karya ilmiah yang di tulis oleh remon lapisa dkk, di jurnal invotek [1].

Metode mengajar guru adalah suatu cara yang digunakan oleh guru dalam melaksanakan atau menyampaikan suatu kegiatan pembelajaran yang telah disusun atau di rencanakan secara optimal agar tercipta suatu kondisi belajar yang efektif, khususnya dalam penyampaian materi pelajaran, sehingga tujuan dari pembelajaran dapat tercapai. Menurut Sarwono, Persepsi siswa tentang metode mengajar guru adalah suatu proses yang terjadi pada diri seorang siswa yang melihat, menangkap, memahami dan mengevaluasi mengenai cara atau prosedur yang digunakan oleh seorang guru dalam menyampaikan materi pembelajaran di kelas [2]. Persepsi siswa dalam metode mengajar guru akan mempengaruhi pikiran siswa dan tindakan siswa dalam proses belajar mengajar sehingga akan berpengaruh terhadap hasil belajar siswa itu sendiri.

Pada saat penulis melakukan praktek kerja lapangan ( PLK) Di SMK N 8 padang, penulis melihat adanya kendala dalam proses belajar mengajar yang akan berdampak pada hasil belajar siswa seperti kurangnya perhatian, tanggapan atau respon siswa terhadap materi yang disampaikan oleh guru. dalam kegiatan pembelajaran dikelas tercermin dalam sikap acuh tak acuh terhadap pelajaran yang diberikan, bermain sendiri, mengganggu temannya, keluar masuk kelas, malas mengerjakan tugas, sering datang terlambat masuk kelas atau bahkan meremehkan gurunya. Sehingga penulis menduga adanya respon atau persepsi yang negatif terhadap cara guru atau metode mengajar guru dalam menyampaikan materi pelajaran di kelas. Persepsi yang negatif dari siswa pada metode mengajar guru dapat menghambat keberhasilan siswa dalam melaksanakan proses pembelajaran di kelas, dan akan berpengaruh kepada hasil belajar yang didapat oleh siswa tersebut. Untuk itu seorang guru diharapkan dapat memberikan contoh yang baik kepada siswa di dalam kelas serta dengan metode mengajar yang baik dalam menyampaikan materi pelajaran di kelas, dan guru dapat menciptakan interaksi belajar mengajar yang kondusif, sehingga di harapkan dapat 
memberikan suatu hasil pembelajaran yang optimal, hasil belajar siswa pun akan lebih baik.

\section{Hasil Belajar}

Hasil belajar menjadi tolak ukur yang dapat digunakan untuk menentukan tingkat keberhasilan siswa dalam menguasai materi pelajaran. Menurut Hamalik mengemukakan bahwa "Hasil belajar bukan suatu penguasaan hasil latihan melainkan perubahan perlakuan" [3].. Selanjutnya Sudjana "hasil belajar merupakan kemampuan yang dimiliki siswa setelah ia menerima pengalaman belajarnya" [4]. Selain itu, menurut Muhibbin Syah menyatakan "hasil belajar meliputi segenap ranah psikologis yang berubah sebagai akibat pengalaman dan proses belajar siswa"[5]. Berdasarkan pendapat ahli tersebut dapat diambil kesimpulan bahwa hasil belajar merupakan kemampuan kognitif yang dimiliki oleh siswa setelah mengikuti proses belajar mengajar yaitu: nilai pada akhir belajar.Nilai inilah yang nantinya sebagai penentu bagi seorang guru, apakah siswa tersebut dapat memahami pelajaran atau tidak.

\section{Persepsi}

Menurut Slameto "Persepsi adalah proses yang menyangkut masuknya pesan atau informasi ke dalam otak manusia"[6]. Melalui persepsi, manusia terus-menerus mengadakan hubungan dengan lingkungannya. Hubungan ini dilakukan lewat inderanya, yaitu indera penglihatan, pendengar, peraba, perasa dan pencium. Sedangkan Menurut Menurut Bimo Walgito Persepsi merupakan proses diterimanya stimulus oleh individu melalui alat indera atau juga disebut proses sensoris [7]. Selanjutnya menurut Martias dalam penelitiannya mengatakan persepsi adalah gambaran atau kesan terhadap sesuatu objek setelah mengamati dan menginterprestasikan sehingga memiliki makna dalam konteks lingkungannya [8]. Dalam hal ini persepsi yang dimaksud adalah persepsi siswa dalam pelaksanaan proses belajar mengajar.

Dari pengertian diatas, dapat disimpulkan persepsi adalah suatu proses, tanggapan, pandangan atau penilaian terhadap sesuatu di mana seseorang menyimpulkan suatu pesan atau informasi yang masuk ke dalam pikiran atau otak manusia melalui panca indera yang dimiliki yang berupa peristiwa berdasarkan pengalamannya..

\section{METODE}

Jenis Penelitian yang digunakan adalah penelitian kuantitatif bersifat korelasional. Menurut Arikunto Menyatakan bahwa Penelitian korelasional merupakan penelitian yang dimaksudkan untuk mengetahui ada tidaknya hubungan antara dua variabel atau beberapa variabel [9]. Hal ini sejalan dengan yang di sampaikan oleh remon lapisa dkk [10] dalam karya ilmiah yang dipresentasikan pada tahun 2017. Penelitian ini dilakukan dengan mengklasifikasikan variabel kedalam dua kelompok yaitu variabel bebas ( $\mathrm{X}$ ) dan variabel terikat $(\mathrm{Y})$. Penelitian ini bertujuan untuk mengetahui Hubungan persepsi siswa Dalam metode mengajar guru Terhadap hasil belajar siswa Teknik Kendaraan Ringan Di SMK N 8 Padang. Populasi penelitian Menurut Syofian menyatakan bahwa populasi penelitian merupakan keseluruhan atau (universum) dari karakteristik atau unit hasil pengukuran yang menjadi objek penelitian[11]. Populasi dalam penelitian ini adalah seluruh siswa kelas XI 
Teknik Kendaraan Ringan Di SMKN 8 Padang Tahun Pelajaran 2017/2018. Populasi penelitian ini dapat dilihat pada tabel 1 berikut:

Tabel 1. : Populasi Penelitian

\begin{tabular}{lll}
\hline No & Kelas & Jumlah Siswa \\
\hline 1 & XI TKR 1 & 23 \\
2 & XI TKR 2 & 22 \\
& Total Jumlah Siswa & 45 siswa \\
\hline
\end{tabular}

Sampel penelitian Menurut Arikunto "Sampel adalah sebagian atau wakil dari populasi yang akan diteliti"[9]. Teknik penarikan sampel dengan cara startified random sampling yaitu suatu teknik pengambilan sampel yang mana sampel diambil secara acak. Berdasarkan data sampel yang di ambil secara proposional, setelah dilakukan pembulatan maka jumlah sampel dalam penelitian ini adalah sebanyak 31 orang siswa. Sumber data primer dalam penelitian ini diperoleh dari penyebaran angket kepada siswa kelas XI Teknik Kendaraan Ringan Di SMKN 8 Padang Tahun Pelajaran 2017/2018 dan sumber data sekunder adalah dokumen hasil nilai ulangan harian siswa TKR semester genap 2017/2018.

\section{HASIL DAN PEMBAHASAN}

\section{Hasil Penelitian}

\section{Deskripsi Data}

Data penelitian ini meliputi dua variabel yaitu persepsi siswa dalam metode mengajar guru $(\mathrm{X})$ dan hasil belajar siswa $(\mathrm{Y})$.

\section{Persepsi siswa dalam metode mengajar guru Mata pelajaraan pemeliharaan mesin kendaraan ringan.}

Sebelum melakukan penyebaran angket kepada responden dilakukan terlebih dahulu uji validitas dan reliabilitas angket. Dari uji coba didapat 37 item yang valid dan reliabel. Setelah memenuhi persyaratan valid dan reliabel maka dilakukan penelitian. Hasil perhitungan statistik dasar persepsi siswa dalam metode mengajar guru mata pelajaran PMKR dapat dilihat pada tabel 2. berikut,

Tabel 2. Perhitungan statistik

\begin{tabular}{clcc}
\hline No & Statistik & Variabel X & Variabel Y \\
\hline 1 & Jumlah sampel & 31 & 31 \\
2 & Rata-rata (mean) & 142,4 & 70,71 \\
3 & Nilai tengah (median) & 142,89 & 71,95 \\
4 & Skor yang sering muncul (modus) & 140,67 & 70,50 \\
5 & Simpangan baku (standar devisiasi) & 8,47 & 9,99 \\
6 & Keragaman (variance) & 77,46 & 114,05 \\
7 & Skor tertinggi & 157 & 90 \\
8 & Skor terendah & 125 & 40 \\
9 & Skor total & 4385 & 2205 \\
10 & Rentang (range) & 32 & 50 \\
\hline
\end{tabular}

Berdasarkan perhitungan statistik dasar dapat dilihat bahwa distribusi skor jawaban menyebar dari skor terendah 125 dan skor tertinggi 157 Berdasarkan distribusi 
skor tersebut didapatkan mean $=142,4$, median $=142,89$, modus $=140,6$, standar devisiasi $=8,47$, range $=32$, variance $=77,46$, dan skor total $=4385$.

Berikut ini tabel 3 adalah distribusi frekuensi skor persepsi siswa dalam metode mengajar guru.

Tabel 3. Distribusi frekuensi persepsi siswa dalam metode mengajar guru

\begin{tabular}{cccc}
\hline No & Interval Kelas & F Absolut & F Relatif (\%) \\
\hline 1 & $125-130$ & 3 & 9,68 \\
2 & $131-136$ & 4 & 12,90 \\
3 & $137-142$ & 9 & 29,03 \\
4 & $143-148$ & 8 & 25,81 \\
5 & $149-154$ & 4 & 12,90 \\
6 & $155-160$ & 3 & 9,68 \\
\hline & Jumlah & 31 & $100 \%$ \\
\hline
\end{tabular}

\section{Hasil belajar}

Data hasil belajar siswa diperoleh dari ujian tengah semester tahun pelajaran 2017/2018 jumlah siswa sebanyak 31 Orang yang di jadikan sampel yang di peroleh dari guru mata pelajaran pemeliharaan mesin kendaraan ringan. Berdasarkan perhitungan ststistik dasar hasil belajar di atas, diperolah nilai terendah 40 dan nilai tertinggi 90 . Berdasarkan nilai tersebut didapatkan mean $=70,71$, median $=67,59, \quad$ modus $=71,83$, standar devisiasi $=9,99$, range $=50$, variance $=114,05$, skor total $=2205$. Untuk lebih jelasnya dapat dilihat pada tabel 4.

Tabel 4. distribusi frekuensi hasil belajar pemeliharaan mesin kendaran ringan

\begin{tabular}{cccc}
\hline No & Interval Kelas & F Absolut & F Relatif (\%) \\
\hline 1 & $40-48$ & 1 & 3,23 \\
2 & $49-57$ & 1 & 3,23 \\
3 & $58-66$ & 8 & 25,81 \\
4 & $67-75$ & 11 & 35,48 \\
5 & $76-84$ & 8 & 25,81 \\
6 & $85-93$ & 2 & 6,45 \\
\hline & Jumlah & 31 & $100 \%$ \\
\hline
\end{tabular}

Dari variabel persepsi siswa dalam metode mengajar guru $(\mathrm{X})$ dan variabel hasil belajar(Y) maka dapat dilihat dalam bentuk diagram yang ada pada gambar 1

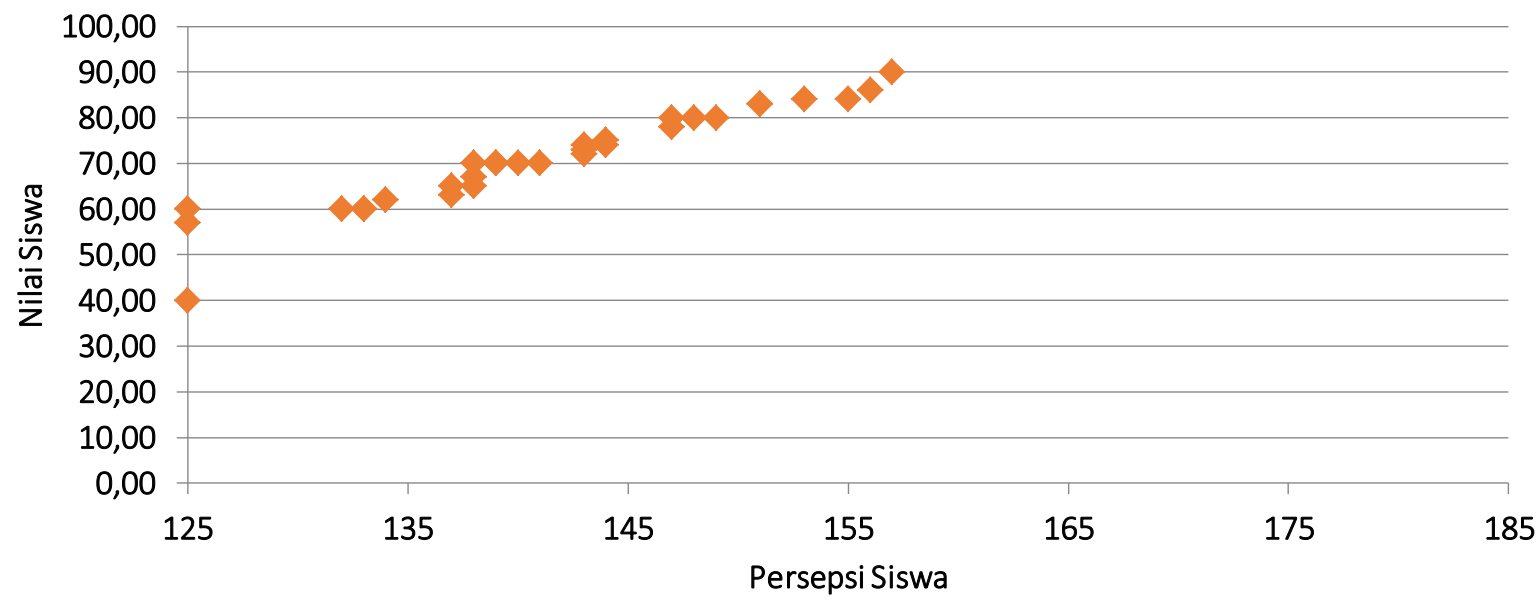

Gambar 1. A. Diagram Persepsi siswa dalam metode mengajar guru terhadap hasil belajar mata pelajaran pemeliharaan mesin kendaraan ringan . 
Pada diagram persepsi siswa dalam metode mengajar guru terhadap hasil belajar mata pelajaraan pemeliharaan mesin kendaraan ringan, menunjukkan bahwa siswa yang memiliki atau yang mempunyai persepsi yang paling rendah atau kurang baik maka akan memiliki nilai yang rendah juga, begitupun seterusnya semakin tinggi atau semakin baik persepsi siswa dalam metode mengajar guru maka nilai yang didapatkan siswa dalam pelajaran tersebut juga semakin baik, namun ada juga beberapa siswa yang memiliki persepsi yang sama nilai nya justru berbeda, mungkin ini salah satunya disebabkan oleh siswa tersebut pintar atau siswa tersebut jarang masuk yang menyebabkan nilainya rendah,

\section{Pengujian pesyaratan analisis}

\section{Uji normalitas}

Pengujian normalitas bertujuan untuk menguji asumsi bahwa data distribusi normal. Uji normalitas dilakukan dengan menggunakan rumus chi kuadrat. Taraf signifikan yang digunakan sebagai dasar menolak atau menerima keputusan normal atau tidaknya suatu data adalah 0,05. Dikatakan normal jika $x_{\text {hitung }}^{2}<x_{\text {tabel. }}^{2}$.

Untuk lebih jelasnya tentang pengujian normalitas dapat dilihat pada tabel 5 . berikut :

Tabel 5. Rangkuman Pengujian Normalitas

\begin{tabular}{lllll}
\hline No & Variabel & $x_{\text {hitung }}^{2}$ & $x_{\text {tabel }}^{2}$ & Keterangan \\
\hline 1 & Variabel (X) & $-27,870$ & 11,070 & Normal \\
2 & Variabel (Y) & $-38,196$ & 11,070 & Normal \\
\hline
\end{tabular}

Dari tabel 5 diatas diatas dapat dilihat nilai chi kuadrat untuk variabel (X) sebesar $-27,870$ dan variabel (Y) $-38,196$ dengan taraf signifikan $(\alpha)=0,05$. Berdasarkan landasan pengambil keputusan diatas maka variabel persepsi siswa dalam metode mengajar Guru (X) dan varibel hasil belajar Pemeliharaan mesin Kendaraan Ringan (Y) adalah distribusi normal.

\section{Uji Linearitas}

Uji linearitas adalah uji yang digunakan untuk melihat apakah masing-masing data variabel Persepsi siswa dalam metode mengajar guru (X) membentuk distribusi linear terhadap variabel hasil belajar pemeliharaan mesin kendaraan ringan (Y). Hasil kelinearan persamaan regresi ditampilkan pada tabel 6 .

Tabel 6. Ringkasan Anova Variabel Y Atas X

\begin{tabular}{|c|c|c|c|c|}
\hline Sumber Variasi & $\begin{array}{l}\text { Derajat } \\
\text { bebas } \\
\text { (db) }\end{array}$ & $\begin{array}{l}\text { Jumlah } \\
\text { Kuadrat } \\
(\mathrm{JK})\end{array}$ & $\begin{array}{l}\text { Rata-rata } \\
\text { Jumlah } \\
\text { Kuadrat } \\
\text { (RJK) }\end{array}$ & $\mathrm{F}_{\text {hitung }}$ \\
\hline Total & 31 & 160261 & - & 0,107 \\
\hline Regresi (a) & 1 & 156839,516 & 156839,516 & \multirow{5}{*}{$\begin{array}{l}\text { Kesimpulan: } \\
\text { Karena } F_{\text {hitung }}<\mathrm{F}_{\text {tabel }} \text { atau } \\
0,107<2,583 \text { maka dapat } \\
\text { Disimpulkan bahwa metode Regresi } \\
\text { linear } Y \\
\text { atas X adalah Linear }\end{array}$} \\
\hline Regresi (b/a) & 1 & 3131,44 & 3131,44 & \\
\hline Residu & 29 & 290,044 & 10,006 & \\
\hline Tuna Cocok $_{(\mathrm{TC})}$ & 17 & 38,211 & 2,247 & \\
\hline Kesalahan $_{\text {(Error) }}$ & 12 & 251,833 & 20,986 & \\
\hline
\end{tabular}

Berdasarkan tabel diatas $\mathrm{F}_{\text {hitung }}<\mathrm{F}_{\text {tabel }}=0,107<2,583$ dengan nilai alpha 0,05 dapat disimpulkan bahwa sebaran data variabel bebas $(\mathrm{X})$ membentuk garis linear dengan variabel terikat (Y). 


\section{Pengujian Hipotesis.}

\section{Analisis Koefisien Korelasi}

Analisis koefisien korelasi dilakukan untuk mengetahui hubungan antara variabel bebas (X) dengan variabel terikat (Y). Kriteria pengujian yang digunakan, jika rhitung > rtabel maka terdapat hubungan yang signifikan antara variabel $\mathrm{X}$ dengan variabel $\mathrm{Y}$ dan apabila rhitung < rtabel maka tidak terdapat hubungan yang signifikan antara variabel $\mathrm{X}$ dan variabel Y.

\section{Analisis Keberartian Koefisien Korelasi}

Kemudian dilanjutkan dengan uji keberatian koefisien korelasi untuk menguji keberatian korelasi menggunakan uji-t hasil analisis dapat dilihat pada tabel 7

Tabel 7. Hasil analisis koefisien korelasi antara variabel X dan Variabel Y

\begin{tabular}{cllll}
\hline No & Pengujian hipotesis & Nilai & \multicolumn{2}{c}{ Keterangan } \\
\hline \multirow{2}{*}{1} & \multirow{2}{*}{ Uji Korelasi } & $\mathrm{r}_{\text {hitung }}$ & $\mathrm{r}_{\text {tabel }}$ & Ada hubungan dan \\
& & 0,957 & 0,355 & signifikan pada $\alpha=$ \\
2 & \multirow{2}{*}{ Uji Keberartian Korelasi } & $\mathrm{t}_{\text {hitung }}$ & $\mathrm{t}_{\text {tabel }}$ & 0,05 dan n $=31$ \\
& & 17,769 & 1,699 & \\
\hline
\end{tabular}

Dari tabel 7 hasil analisis koefisien korelasi antara variabel $\mathrm{X}$ dan Variabel $\mathrm{Y}$ diperoleh pearson corelation $=0,957$. Karena harga $r$ hitung $>r$ tabel $(0,957>0.355)$ pada $\alpha=0,05$ ini menunjukan antara persepsi siswa dalam metode mengajar guru (X) dengan hasil belajar siswa terdapat hubungan yang positif dan signifikan. Ho ditolak dan Ha diterima. Sedangkan analisis keberartian korelasi Kriteria yang digunakan adalah apabila $\mathrm{t}$ hitung $>\mathrm{t}$ tabel maka hipotesis penelitian diterima. Karena $\mathrm{t}$ hitung $17,769>\mathrm{t}$ tabel 1,699, sehingga hipotesis yang menyatakan bahwa "bahwa Persepsi siswa dalam metode mengajar guru (X) mempunyai hubungan yang positif dan signifikan terhadap hasil belajar siswa pada kompetensi Pemeliharaan mesin Kendaraan Ringan teknik kendaraan ringan SMK Negeri 8 Padang (Y)." diterima dengan taraf signifikan 0,05 .

\section{Deskripsi data}

Persepsi siswa dalam metode mengajar guru mata pelajaran pemeliharaan sasis dan pemindah tenaga kendaraan ringan.

Hasil perhitungan statistik dasar persepsi siswa dalam metode mengajar guru mata pelajaran pemeliharaan sasis dan pemindah tenaga kendaraan ringan dapat dilihat pada tabel 8. berikut,

Tabel 8. Rangkuman Perhitungan Statistik Dasar

\begin{tabular}{cllc}
\hline No & Statistik & Variabel X & Variabel Y \\
\hline 1 & Jumlah sampel & 31 & 31 \\
2 & Rata-rata (mean) & 146,81 & 74,40 \\
3 & Nilai tengah (median) & 148,63 & 74,55 \\
4 & Skor yang sering muncul (modus) & 145,50 & 76,68 \\
5 & Simpangan baku (standar devisiasi) & 10,38 & 11,44 \\
6 & Keragaman (variance) & 94,33 & 118,80 \\
7 & Skor tertinggi & 163 & 92 \\
8 & Skor terendah & 128 & 50 \\
9 & Skor total & 4555 & 2294 \\
10 & Rentang (range) & 35 & 42 \\
\hline
\end{tabular}

Berdasarkan perhitungan statistik dasar distribusi skor jawaban menyebar dari skor terendah 128 dan skor tertinggi 163 Berdasarkan distribusi skor tersebut 
didapatkan mean $=146,81$, median $=148,63$, modus $=145,50$, standar devisiasi $=$ 10,38 , range $=35$, variance $=94,33$, dan skor total $=4555$. Berikut ini tabel 9 . distribusi frekuensi skor Persepsi siswa dalam metode mengajar guru:

Tabel 9. distribusi frekuensi skor persepsi siswa dalam metode mengajar guru

\begin{tabular}{clcc}
\hline No & Interval Kelas & F Absolut & F Relatif (\%) \\
1 & $128-134$ & 4 & 12,90 \\
2 & $135-141$ & 6 & 19,35 \\
3 & $142-148$ & 8 & 25,81 \\
4 & $149-155$ & 7 & 22,58 \\
5 & $156-162$ & 3 & 9,68 \\
6 & $163-169$ & 3 & 9,68 \\
\hline & Jumlah & 31 & $100 \%$ \\
\hline
\end{tabular}

\section{Hasil belajar pemeliharaan sasis dan pemindah tenaga kendaraaan ringan}

Data hasil belajar siswa diperoleh dari ujian tengah semester tahun pelajaran 2017/2018 jumlah siswa sebanyak 31 Orang yang di jadikan sampel yang di peroleh dari guru mata pelajaran. Berdasarkan perhitungan statistic dasar hasil belajar di atas, diperoleh nilai terendah 50 dan nilai tertinggi 92. Berdasarkan nilai tersebut didapatkan mean $=74,40$, median $=74,53$, modus $=76,68$, standar devisiasi $=11,44$, range $=42$, variance $=118,80$, dan skor total $=2294$. Untuk lebih jelasnya dapat dilihat pada tabel 10.

Tabel 10.distribusi frekuensi hasil belajar pemeliharaan sasis \& pemindah tenaga

\begin{tabular}{llll}
\hline No & Interval Kelas & F Absolut & F Relatif $(\boldsymbol{\%})$ \\
\hline 1 & $50-57$ & 3 & 9,68 \\
2 & $58-65$ & 4 & 12,90 \\
3 & $66-73$ & 6 & 19,35 \\
4 & $74-81$ & 10 & 32,26 \\
5 & $82-89$ & 5 & 16,13 \\
6 & $90-97$ & 3 & 9,68 \\
\hline Jumlah & & 31 & $100 \%$ \\
\hline
\end{tabular}

Dari variabel persepsi siswa dalam metode mengajar guru $(\mathrm{X})$ dan variabel hasil belajar(Y) maka dapat dilihat dalam bentuk diagram di gambar 2



Gambar 2. Diagram Persepsi siswa dalam metode mengajar guru terhadap hasil belajar siswa mata pelajaran pemeliharaan sasis dan pemindah tenaga 
Pada diagram persepsi siswa dalam metode mengajar guru terhadap hasil belajar siswa mata pelajaran pemeliharaan sasis dan pemindah tenaga kendaraan ringan menunjukan adanya peningkatan persepsi siswa lebih baik dari mata pelajaran sebelumnya dan nilai yang didapatkan siswa juga semakin baik, serta nilai yang di dapatkan oleh siswa juga bervariasi, namun ada juga beberapa siswa yang memiliki nilai yang sama, persepsi nya justru berbeda, mungkin ini di sebabkan oleh guru tersebut baik dalam mengasih nilai siswa dan ada juga siswa yang memilki persepsi yang sama nilainya juga sama, ini mungkin disebabkan oleh siswa tersebut mencontek/ meniru temannya saat melakukan ulangan atau siswa tersebut mencontek/ meniru angket penelitian yang peneliti sebarkan saat peneliti melakukan penelitian.

\section{1. uji normalitas}

Pengujian normalitas bertujuan untuk menguji asumsi bahwa data distribusi normal. Uji normalitas dilakukan dengan menggunakan rumus chi kuadrat. Taraf signifikan yang digunakan sebagai dasar menolak atau menerima keputusan normal atau

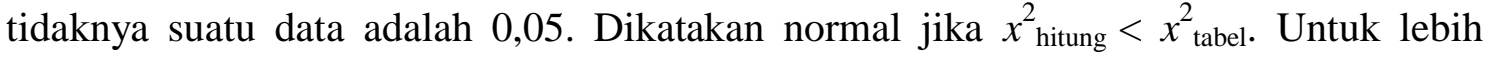
jelasnya tentang pengujian normalitas dapat dilihat pada tabel 11

Tabel 11. rangkuman pengujian normalitas.

\begin{tabular}{lllll}
\hline No & Variabel & $x_{\text {hitung }}^{2}$ & $x_{\text {tabel }}^{2}$ & Keterangan \\
\hline 1 & Variabel $(\mathrm{X})$ & $-19,507$ & 11,070 & Normal \\
2 & Variabel $(\mathrm{Y})$ & $-30,429$ & 11,070 & Normal \\
\hline
\end{tabular}

Dari tabel 11 dapat dilihat nilai chi kuadrat untuk variabel (X) sebesar -19,507 dan variabel (Y) $-30,429$ dengan taraf signifikan $(\alpha)=0,05$. Berdasarkan landasan pengambil keputusan diatas maka variabel persepsi siswa dalam metode mengajar guru(X)dan varibel hasil belajar Pemeliharaan sasis dan pemindah tenaga Kendaraan Ringan(Y) adalah distribusi normal.

\section{Uji Linearitas}

Uji linearitas adalah uji yang digunakan untuk melihat apakah masing-masing data variabel metode mengajar guru (X) membentuk distribusi linear terhadap variabel hasil belajar pemeliharaan sasis dan pemindah tenaga kendaraan ringan (Y). Hasil kelinearan persamaan regresi ditampilkan pada tabel 12

Tabel 12. Ringkasan anova variabel $\mathrm{Y}$ atas $\mathrm{X}$

\begin{tabular}{|c|c|c|c|c|}
\hline Sumber Variasi & $\begin{array}{l}\text { Derajat } \\
\text { bebas } \\
(\text { db) }\end{array}$ & $\begin{array}{l}\text { Jumlah } \\
\text { Kuadrat } \\
\text { (JK) }\end{array}$ & $\begin{array}{l}\text { Rata-rata } \\
\text { Jumlah } \\
\text { Kuadrat } \\
\text { (RJK) }\end{array}$ & $\mathbf{F}_{\text {hitung }}$ \\
\hline Total & 31 & 173322 & - & $-0,621$ \\
\hline Regresi (a) & 1 & 169756 & 169756 & \multirow{4}{*}{$\begin{array}{l}\text { Kesimpulan: } \\
\text { Karena } \mathrm{F}_{\text {hitung }}<\mathrm{F}_{\text {tabel }} \text { atau } \\
-0,621<2,671 \text { maka dapat } \\
\text { Disimpulkan bahwa metode }\end{array}$} \\
\hline Regresi (b/a) & 1 & 3312,02 & 3312,02 & \\
\hline Residu & 29 & 25398 & 8,758 & \\
\hline Tuna Cocok ${ }_{(\mathrm{TC})}$ & 18 & 14581,647 & 810,091 & \\
\hline Kesalahan $_{\text {(Error) }}$ & 11 & $-14327,667$ & $-1302,515$ & atas $X$ adalah Linear \\
\hline
\end{tabular}

Berdasarkan tabel $12 \mathrm{~F}_{\text {hitung }}<\mathrm{F}_{\text {tabel }}=-0,621<2,671$ dengan nilai alpha 0,05 dapat disimpulkan bahwa sebaran data variabel bebas $(\mathrm{X})$ membentuk garis linear dengan variabel terikat $(\mathrm{Y})$. 


\section{Pengujian Hipotesis.}

\section{Analisis Koefisien Korelasi}

Analisis koefisien korelasi dilakukan untuk mengetahui hubungan antara variabel bebas $(\mathrm{X})$ dengan variabel terikat (Y). Kriteria pengujian yang digunakan, jika rhitung > rtabel maka terdapat hubungan yang signifikan antara variabel $\mathrm{X}$ dengan variabel $\mathrm{Y}$ dan apabila rhitung < rtabel maka tidak terdapat hubungan yang signifikan antara variabel $\mathrm{X}$ dan variabel Y.

\section{Analisis Keberartian Koefisien Korelasi}

Kemudian dilanjutkan dengan uji keberatian koefisien korelasi untuk menguji keberatian korelasi menggunakan uji-t hasil analisis dapat dilihat pada tabel berikut ini

Tabel 13. Hasil analisis koefisien korelasi antara variabel X dan Variabel Y

\begin{tabular}{lllll}
\hline No & Pengujian hipotesis & nilai & & Keterangan \\
\hline \multirow{2}{*}{1} & \multirow{2}{*}{ Uji Korelasi } & rhitung & r tabel & Ada hubungan dan \\
& & 0,964 & 0,355 & signifikan pada $\alpha=$ \\
2 & \multirow{2}{*}{ Uji Keberartian Korelasi } & thitung & ttabel & 0,05 dan n = 31 \\
& & 19,522 & 1,699 & \\
\hline
\end{tabular}

Dari tabel 13 hasil analisis koefisien korelasi antara variabel $\mathrm{X}$ dan Variabel $\mathrm{Y}$ diperoleh pearson corelation $=0,964$. Karena harga $r$ hitung $>r$ tabel $(0,964>0.355)$ pada $\alpha=0,05$ ini menunjukan terdapat hubungan yang positif dan signifikan. Ho ditolak dan Ha diterima. Sedangkan analisis keberartian korelasi Kriteria yang digunakan adalah apabila $\mathrm{t}$ hitung $>\mathrm{t}$ tabel maka hipotesis penelitian diterima. Karena $\mathrm{t}$ hitung 19,7522 > t tabel 1,699, sehingga hipotesis yang menyatakan bahwa "bahwa Persepsi siswa dalam metode mengajar guru (X) mempunyai hubungan yang positif dan signifikan terhadap hasil belajar siswa pada kompetensi Pemeliharaan sasis \& PT TKR SMK Negeri 8 Padang (Y).” diterima dengan taraf signifikan 0,05.

\section{Pembahasan}

Berdasarkan hasil analisis data dan pengujian hipotesis diperoleh koefisien korelasi sebesar 0,957 dengan $\alpha=0,05$. Koefisien korelasi ( $\mathrm{r}_{\text {hitung }}$ ) lebih besar dari $\mathrm{r}_{\text {tabel }}$ product moment $(0,957>0,355)$. Setelah harga $r$ dikonsultasikan dengan tabel interprestasi koefisien korelasi $\mathrm{r}$ maka dapat disimpulkan bahwa tingkat hubungan antara variabel $\mathrm{X}$ dengan variabel $\mathrm{Y}$ tergolong cukup kuat dengan besar nilai $\mathrm{r}=0,957$.

Pada pengujian keberartian korelasi didapat $t_{\text {hitung }}>t_{\text {tabel }}(17,769>1,699)$ dengan $\alpha$ $=0,05$. Sedangkan untuk mata pelajaran kompetensi PSDP TKR SMK Negeri 8 Padang (Y) yaitu sebesar 0,964 dengan $\alpha=0,05$. Koefisien korelasi $\left(\mathrm{r}_{\text {hitung }}\right)$ lebih besar dari $r_{\text {tabel }}$ product moment $(0,964>0,355)$. Setelah harga $r$ dikonsultasikan dengan tabel interprestasi koefisien korelasi $\mathrm{r}$ maka dapat disimpulkan bahwa tingkat hubungan antara variabel $\mathrm{X}$ dengan variabel $\mathrm{Y}$ tergolong cukup kuat dengan besar nilai $\mathrm{r}=0,964$. Pada pengujian keberartian korelasi didapat $t_{\text {hitung }}>t_{\text {tabel }}(19,522>1,699)$ dengan $\alpha=$ 0,05 .

Berdasarkan hasil penelitian dapat disimpulkan bahwa penelitian ini sesuai dan saling mendukung dengan kajian teoritis yang secara umum menyatakan bahwa ada hubungan yang positif dan berarti antara Persepsi siswa dalam metode mengajar guru terhadap hasil belajar siswa TKR SMK Negeri 8 Padang. 
Kedua mata pelajaran ini baik mata pelajaran PMKR dan pemeliharaan sasis dan pemindah tenaga kendaraan ringan menunjukan adanya hubungan yang positif yang signifikan Ini berarti semakin baik persepsi siswa atau pandangan siswa dalam metode mengajar guru maka akan semakin baik pula hasil belajar siswa yang didapatkan.

\section{KESIMPULAN DAN SARAN}

Terdapat hubungan yang positif dan signifikan antara Persepsi siswa dalam metode mengajar guru terhadap hasil belajar siswa Pada kompetensi PMKR, TKR SMK Negeri 8 Padang dengan koefisien korelasi $r_{\text {hitung }}(0,957)>r_{\text {tabel }}(0,355)$ dan $t$ hitung $(17,769)>t$ tabel $(1,699)$. Tingkat kekuatan hubungan sebesar $(r=0,957)$. 2. Untuk mata pelajaran Pemeliharaan sasis dan pemindah tenaga kendaraaan ringan juga Terdapat hubungan yang positif dan signifikan antara Persepsi siswa dalam metode mengajar guru terhadap hasil belajar siswa Pada kompetensi pemeliharaan sasis dan pemindah tenaga kendaraan ringan, TKR SMK Negeri 8 Padang dengan koefisien korelasi $r$ hitung $(0,964)>r$ tabel $(0,355)$ dan $t$ hitung $(19,522)>t$ tabel $(1,699)$. Tingkat kekuatan hubungan $(\mathrm{r}=0,964)$ cukup kuat.

Saran untuk Siswa, pada saat pelajaran berlangsung hendaknya siswa memperhatiakan guru, aktif bertanya dan lebih menghargai guru di depan kelas. Kemudian saran bagi guru, sebaiknya sebelum menyampaikan meteri pelajaran di kelas, hendaknya guru dapat menerapkan dan memperhatikan metode mengajar yang tepat bervariasi dan tidak monoton dalam mengajar sehingga siswa tidak bosan dan jenuh di dalam proses pembelajaran siswa di kelas. Lalu saran bagi penelitian berikutnya agar dapat memperdalam lagi pembahasan mengenai faktor-faktor yang mempengaruhi hasil belajar siswa, baik itu faktor dalam diri maupun luar diri siswa dan faktor faktor pendukung lainya.

\section{REFERENSI}

[1] Lapisa R, Basri IY, Arif A, saputra Hd. Peningkatan kompetensi siswa melalui pelatihan auto cad. Invontek inovasi vokasinal dan teknologi 2017: 17: 119-126.

[2] Sarwono, Sarlito. 2009. Pengantar Psikologi Umum. Jakarta: Rajawali Press

[3] Hamalik, Oemar (2001). Psikologi Belajar dan Mengajar. Bandung: Sinar Baru Algesindo.

[4] Sudjana N,(2010).Dasar-Dasar Proses BelajarMengajar.Bandung:PT Sinar BaruAlgensindo

[5] Syah Muhibbin. (2014). Psikologi belajar. Jakarta: PT. Raja Grafindo Persada

[6] Slameto. (2015). Belajar dan Faktor-Faktor yang Mempengaruhi. Jakarta : PT. Rineka Cipta

[7] Walgito Bimo. (2010).Pengantar Psikologi Umum.Yogyakarta.Andi Offset

[8] Martias, (2014). Hubungan Persepsi Siswa Tentang Pelaksanaan Proses Belajar Mengajar Mata Diklat Las Dengan Hasil Belajar Siswa Kelas X Teknik Kendaraan Ringan Di Smk Negeri 8 Padang.

[9] Arikunto,S(1998). Prosedur Penelitian SuatuPendekatanPraktek.Jakarta:Rineke Cipta

[10]Lapisa R, Putra DS, utama Md, setiawan d, ambiyar. evaluation of learning process using CIIP model. 4th internasional conference on technical and vocational education and training UNP -2017, vol. 1, padang: UNP Press: 201 
[11] Syofian. 2013. Statistic Parametrik Untuk Penelitian Kuantitatif Dilengkapi Dengan Perhitungan Manual Dan Aplikasi SPSS Versi 17. Jakarta Bumi Aksara 